HENNING GOLDBAK

Lektor emeritus i litteraturvidenskab ved Syddansk Universitet

\title{
SMERTENS APRIORI OM PETER SLOTERDIJK OG HISTORIENS GENKOMST
}

\section{THE A-PRIORI PAIN - AN ESSAY ON PETER SLOTERDIJK AND THE RETURN OF}

HISTORY | Sloterdijk's claim, in Critique of Cynical Reason and in later books, that nobody knows, what it means to be modern, is related to the Hegelian tradition that still defines modern history as mythical history, and locates non-mythical history in a Utopian future. Sloter-

dijk's late works, especially Spheres I-III, are an attempt to analyse the reasons, why modern individuals are still mentally living in the past and harmonic world of Plato's ideas, Aristotle's ethics and Plotin's emanations, instead of accepting the fragmentarian world of modernity and globalization. And last but not least Sloterdijk's books on Nietzsche are completely different from any other contemporary books on his philosophy. Nietzsche was the first modern thinker, who realized, that the death of God was the trauma of his time, and that it would take centuries to understand the full extent of the catastrophe, before we could even think of becoming modern. According to Sloterdijk we are still suffering from the a-priori Pain, we have only been modern for 100 years, since the First World War, and Sloterdijk's hero is not the revolutionary, nor the left-wing student, but asceticism and the modern athlete, who lives from surpassing himself. Of course Sloterdijk is still longing for the return of history, but he keeps asking himself: The return of which history?

KEYWORDS I philosophy, history, psychology, literature, modernity

\section{Hvem er Sloterdijk?}

Siden den tyske filosof Peter Sloterdijk ${ }^{\mathrm{I}}$ udgav Kritik af den kyniske fornuft i I983, har han stået som den, der gjorde op med den gamle frankfurterskoles historiepessimisme, især med ånden i Th. W. Adornos Negativ Dialektik, fra 1964, hvis første sætning lyder:

"Filosofien, der engang forekom forældet, holder sig i live, fordi øjeblikket for dens realisering udeblev" (Adorno I5). 
I forordet til Den kyniske fornuft hedder det derimod med klar reference til Adornos sætning:

"De sidste hundrede år har filosofien ligget for døden og kan ikke dø, fordi dens opgave ikke er opfyldt” (Sloterdijk, Kritik 7).

Sloterdijks sætning er skrevet som en kommentar til Adorno, spørgsmålet er blot, om det er en kritisk kommentar, som sekundærlitteraturen til Sloterdijks forfatterskab entydig mener, eller om Sloterdijk ikke snarere tænker videre i Adornos tradition, hvor den filosofi, hvis realisering udeblev, får et efterliv, som Sloterdijk således er med til at genbruge og videreudvikle. Det er dette paradoks mellem Sloterdijk, der bryder med den kritiske teori og Sloterdijk, der arbejder videre i den kritiske teoris tradition, som er emnet for denne artikel. Der er en særlig grund til at stille dette spørgsmål, for den danske oversættelse af Sloterdijks Kritik af den kyniske fornuft har desværre ${ }^{2}$ udeladt denne bogs anden halvdel, som er et ægte kritisk teoretisk projekt: en analyse af kynismen hos de tyske intellektuelle over for Weimarrepublikken, versus forsøget på at redde centrale ord som opvågning og myte fra nazismens propaganda blandt andet gennem inddragelse af dybdepsykologi og studier af den autoritære karakter. Det er et område, Sloterdijk arbejder videre med i Spheren I-III (Sfærer I-III) under navnet nobjektteori.

Udgangspunktet for denne artikel er, at Sloterdijks forfatterskab ikke er baseret på et brud med den kritiske teori som indbegrebet af kynisme, men at det tværtimod er en videretænkning og en immanent kritik af dette projekt. Udgangspunktet er desuden, at Sloterdijk i stedet for at bryde med den kritiske teori, udnytter de store brudflader inden for den, mellem Adorno og Max Horkheimer på den ene side og Walter Benjamin og Ernst Bloch på den anden side, for eksempel i forholdet til myte, oplysning, Martin Heidegger, C.G. Jung og Oswald Spengler. Udgangspunktet er endelig, at spørgsmålet om historiens genkomst hos Sloterdijk netop er et eksempel på hans ståsted i forhold til den kritiske teori, fordi han som den stadig skelner mellem mytisk tid helt op til nutiden og en historiefilosofi, baseret på myndige individer, der knap nok er begyndt at tage form endnu. Det er derfor, han bruger Spenglers morfologiske historieopfattelse i Vesterlandets Undergang, hvor al historie indtil nutiden bevæger sig cirkulært i rum med begyndelse-midteundergang, for det svarer til mytens cirkulære bevægelse, og så længe, der ikke findes en virkelig historie, så er netop Spengler og andre, der deler hans historiesyn, bedst til at gøre opmærksom, hvor vi befinder os i menneskehedens udvikling.

2 Udeladelsen har tydeligvis medført en unuanceret reception af Sloterdijk i dansk sammenhæng, hvor billedet af ham stort set svarer til den tyske sekundærlitteraturs beskrivelser, og hvor der skelnes alt for bastant mellem kynisme som negativt og cynisme som positivt, uden at se begrebsparrets indre sammenhæng i en historiefilosofisk sammenhæng. Og Sloterdijks brug af begrebsparret i forbindelse med analysen af de tyske intellektuelles forhold til nazismen og Weimarrepublikken er helt fraværende. 


\section{Bjarne Riis og den gule forertrøje}

Kritik af den kyniske fornuft, der udkom i 200-året for udgivelsen af Kants Kritik af den rene fornuft, blev en international bestseller, og begyndelsen til en multimediekarriere for forfatteren. Sloterdijk er i dag universitetsprofessor og rektor, han optræder i den populære udsendelse Im Glashaus: Das Philosophische Quartett (I glashuset. Den filosofiske kvartet), han har udgivet bøger om mange store filosoffer med tekstudvalg, der svarer til de citater han selv bruger i sine bøger, når han omtaler Platon, Aristoteles, Augustin, Descartes, Kant, Hegel, Marx, Nietzsche, Heidegger, Sartre og Foucault. Indtil dato har han udgivet cirka 30 bøger, flere af dem store og vigtige forskningsarbejder. Der findes allerede adskillige bøger om ham, ikke kun på tysk, men også på engelsk, og for de fleste af bøgerne gælder det, at de er hyldestskrifter til Sloterdijks verdensanskuelse, men sjældent kritiske og spørgende. Som det er tilfældet med Thomas Mann, Joyce og andre store forfattere, er det lykkedes for Sloterdijk at bygge en næsten uigennemtrængelig mur op omkring sig af myter og store fortællinger, som biografierne og festskrifterne om ham vidner om.

Sloterdijks skrifter er svære at bestemme på grund af hans paradokser, og ikke mindst, fordi han både er tænker og digter, essayist, skuespiller, politiker, uden for og inden for universitetsverdenen, og han er ikke indbegrebet af en tysk fagfilosof. 3 En af hans seneste bøger hedder Mein Frankreich (Mit Frankrig), den handler om, at Tyskland og Frankrig efter 1945 har et fælles efterliv, uden had og ressentiment, men også med muligheder for at se hinanden i kortene på en ny måde. Sloterdijk går i Tyskland for at være postmoderne, fordi han har kritiseret frankfurterskolen, men selv om han ofte citerer Foucault, Derrida og Deleuze, er han også kritisk over for dem, og på mange måder, som vi skal se, er han en stor moralist, hvilket kommer til udtryk i bogen om Frankrig, hvor Sloterdijk som cykelrytter i sin fritid har kørt op til toppen af Tour de France-løbets vigtige Mont Vertoux på toenhalv time, dog som amatør inden for cykelsporten. Men også som cykelrytter kommer hans nietzscheanske moralisme og opbyggelighed til orde i et interview med en kommentar til Bjarne Riis, der efter sin sejr i Tour de France i 1996 (eller efter fratagelsen af den i 2007) sagde: "Den gule førertrøje ligger i en papkarton i min garage. I kan bare komme og hente den.”

"Sloterdijk: Det burde aldrig være sagt, det er toppen af dansk nihilisme. Det er toppunktet af uopdragenhed hos det sidste menneske. Den engang så store cykelrytter var en nietzscheaner i bjergene, en som man lagde mærke til, når han overvandt tyngdekraften og blev et overmenneske. Nu træder pseudoovermennesket frem som det sidste menneske og bøvser ind i alle mikrofoner. Selv symbolet på hans største succes betyder mindre for ham end ingenting. Det viser sig, at denne højere dimension aldrig har eksisteret for ham, ingen æresfølelse, ikke et symbolsk mere, 
ingen glans, ingen spænding fra oven - førertrøjen ikke andet end en meningsløs klud. Hvis man nedgør sportens æresdimension og dens symboler, så er alt forbi.” (Sloterdijk, Mein Frankreich 242)4

\section{Cynisme og kynisme}

Der står næsten ingenting om Kant i Kritik af den kyniske fornuft, ingen solid gennemgang af de tre kritikker, 5 men derimod finder man et hav af referencer til strømninger og tendenser omkring året I983: Karnevalisme, borgerlig offentlighed, erkendelsesinteresse, negativ dialektik, håbets princip, postmodernisme, eksistensfilosofi, og tilbageskuende undersøgelser af især fransk oplysningstænkning, af antikkens cynisme, og dens forvandling til kynisme i oplysningens tidsalder og frem til I983. Det, der fylder mest i bogen, er en gennemgang af cynisme og kynisme i Weimarrepublikken og nazismen. Det har ikke manglet på forsøg på at få greb om denne mangfoldighed af tendenser, Sloterdijks fortolkere betragter bogen som stadig præget af Habermas og Adorno, men i virkeligheden allerede på vej mod Heideggers værensfilosofi og tilbage til Nietzsches omvurdering af alle værdier, alt det som spiller en rolle for Sloterdijks filosofiske hovedværk Sferer I-III, I998-2004.

Cynisme og kynisme ses ofte som modsætninger hos hans fortolkere, ikke mindst i de mange solidariske bøger om hans forfatterskab, hvor kynisme er negativt og cynisme positivt, men faktisk er det ofte meget svært at skelne mellem de to begreber, og det er en pointe hos Sloterdijk, at det er sådan. Et andet nøgleord i hans filosofi er smertens apriori. Og et nøgleafsnit i Den kyniske fornuft hedder "Transcendental polemik", som er en henvisning til den transcendentale elementarlære i Kants Kritik af den rene fornuft, der behandler den rene erkendelses aprioriske forudsætninger, tid og rum, årsag og virkning, fornuft, ideer. Men der står ikke noget om smerte hos Kant selv, eller hos hans mange arvtagere fra den tyske idealisme til nykantianismen, som prioriterede den naturvidenskabelige side af Kant og nedtonede moral og æstetik, hvor ordet smerte kunne få en betydning.

Sloterdijk skriver sig derimod ind $i$ en lang tradition for at genopdage den paradoksale og modsætningsfyldte side af Kant, det er en tradition, der begynder omkring første verdenskrig med Ernst Bloch, Walter Benjamin, Theodor W. Adorno og ikke mindst Jürgen Habermas, som Sloterdijk omtaler i Kritik af den kyniske fornuft:

4 Som man vil se i slutningen af Sfarer III, så er sportsmanden ifølge Sloterdijk indtil videre det bedste eksempel på det nye moderne menneske, der har frigjort sig fra fortiden, og repræsenterer fremtidens utopi, det er ikke mere arbejderen eller studenten eller den professionelle revolutionær, men snarere den professionelle cykelrytter, hvis præstationer Sloterdijk selv prøver at praktisere i sin fritid.

5 Denne tendens er gennemgående hos Sloterdijk, han er ikke fagfilosof, han er tænker og digter, og bruger de citater fra Heidegger, Foucault, Deleuze og andre, som passer ind i hans aktuelle sammenhæng. Derfor kan man opleve, at Heidegger er vigtig i den ene bog af Sloterdijk, men helt fraværende eller forkastelig i den næste. Det er ofte citater, Sloterdijk er optaget af, ikke værkernes indre sammenhæng, eller deres virkningshistorie. Undtagelserne er den kritiske teori, Spengler og Nietzsche. 
"Arbejde og interaktion krydses fra første færd af krig og eros, fjendskaber og forsoninger, udslettelser og skabelser. Uanset hvad der skal erkendes ud fra arbejdets eller interaktionens interesser, så har det altid allerede en 'teoriform', der er stemplet af det polemiske eller det erotiske; uanset hvilken form for 'objektivitet' man vælger, så er det ingenlunde et uskyldigt alternativ; desuden er der en kategorisk forskel på, hvilken form for nøjagtighed man beslutter sig for, om det er polemikerens eller elskerens; hvis det faktisk er et apriorisk alternativ, så burde der være en dobbelt videnskab om alting" (Sloterdijk, Kritik 653).

Citatet er en kritik af Teori om den kommunikative handlen af Habermas, der udkom i I98I. Sloterdijk mener ikke, at dobbeltsporet arbejde og interaktion tager højde for det disharmoniske i historien, Habermas' kommunikationsteori stræber under alle omstændigheder mod enighed, og ikke, som Sloterdijk ønsker det, mod at integrere uenighed, dissensus. Her ligger Sloterdijk snarere på linje med Lyotard, der netop også kritiserede Habermas for at absolutere enighed og udelukke alt det, der faldt uden for formålsrationaliteten. Lyotard nøjedes ikke med at angribe Habermas for at have et indskrænket historiebegreb, han anklagede faktisk hele den vestlige filosofi siden Platon for at ligge under for de store fortællinger og overse de små fortællinger, og resten af sit forfatterskab brugte han på at genlæse og revidere synet på Kant som formålsrationalitetens filosof. Men på det punkt ligger Sloterdijk ikke kun på linje med Lyotard, men også på linje med Adorno, der i Oplysningens Dialektik og Negativ Dialektik går langt videre end Habermas, og affejer kommunikativ handling som magtsprog. Den anden videnskab, som Sloterdijk efterlyser i citatet, refererer til den genopdagelse af Kant, som fandt sted omkring første verdenskrig, da Bloch, Benjamin, Siegfried Kracauer og Adorno alle gik bagom nykantianernes og Hegels Kantopfattelse og gjorde Kant til en revolutionær filosof, der ikke havde formålsrationaliteten som sit hovedformål, men tværtimod definerede rammer for sikker erkendelse præcist for derefter at kunne fremhæve alt det i historien, der ikke var ren erkendelse, men brudfyldt historie, for eksempel etik, æstetik og metafysik. Alt det havde Hegel ganske vist også gjort, da han talte om "Kants tre sjælesække” for ren fornuft, praktisk fornuft og dømmekraft, og ophævede forskellen mellem det aprioriske og tingen i sig selv i sin dialektik. Men kun for at gentage Kants indsnævring af historien til formålsrationalitetens historie, ved at lade sin dialektik gå op i det positive, så det sande altid var det fornuftige. Alt det kritiserer nymarxisterne allerede fra I92oerne, ikke mindst Benjamin, og senere Adorno, hvis Negativ Dialektik netop kaldes negativ, fordi han ikke lader dialektikken slå om og blive positiv, men altid bevarer en rest mellem negation og negationens negation.

Sloterdijks pointe er, at selv om der er gjort alle de bestræbelser på at kritisere og revidere Kants formålsrationalitet og Hegels positive dialektik, ved at være polemisk over for Kant og Hegel, så ender også nymarxismen med at lade polemikken blive til dialektik, og "sejrfantasi". Derfor konkluderer Sloterdijk i Kritik af den kyniske fornuft: 
"Dermed får vi følgende ironiske resultat: Positiv dialektik fra Platon til Lenin virker i praksis som forhindringer og forfalskninger af det, de gjorde til deres tema: den produktive strid og udligningen af kræfterne.” (Sloterdijk, Kritik 682)

Der er altså ikke tale om, at Sloterdijk afviser alle tidligere forsøg på at udvide forståelsen af historien som andet og mere end formålsrationalitet og positiv dialektik, hans bog er jo en grundig opregning af alle disse forsøg, men de er ikke gået vidt nok, mener han, de er alle endt med at bekræfte det positive, selv om de godt ved, at de på den måde udgrænser det ubevidste, det kontingente, smertens apriori. Og det gør dem til kynikere, for selv om de ved, hvad de er med til at undertrykke i kraft af deres tænkning, så fortsætter de med at gøre det, med smerte, beklagelse, melankoli og opgivende mine. Sloterdijk definerer denne moderne form for kynisme som "oplyst falsk bevidsthed", egentlig ikke meget forskellig fra den sene Lukács, der hånligt sagde, at Adorno opholdt sig i bedste velgående på "Hotel Afgrund".

Problemet er blot, at denne moderne kynisme ikke står i modsætning til den cynisme, som Sloterdijk nu giver sig til at udrede som modbillede ved først at gå tilbage til antikken og især tilbage til den kyniske filosof Diogenes og derefter frem til Weimarrepublikkens tidsalder, hvor cynisme og kynisme mødes og skilles.

Ligesom Heidegger, Adorno/Horkheimer og Foucault mener Sloterdijk, at man må gå tilbage til tiden før Platon og Aristoteles for at finde et alternativ til nutidens fejlslagne historie, og for hans vedkommende bliver det Diogenes, latterens filosof, der gennem sit kropssprog - tunge, mund, blik, bryster, røv, prut, lort, genitaler - fysiognomisk protesterer mod Platons idealisme og dermed mod hele den efterfølgende vestlige filosofi. Sloterdijk ser ikke denne udvikling som dialektisk, han bruger ordet "Umpolung" - ompoling, omvending - for den moderne kyniker fra oplysningen til nutiden ser alt som "lort, hans overskuffede overjeg ser ikke det gode ved lorten. Derfor hans nausée.” I stedet for en selvbekræftende dialektik opererer Sloterdijk med en morfologi, når han skal forklare sin historieopfattelse, historien bevæger sig i stadier, ligesom det er tilfældet hos Spengler, hvis bog Vesterlandets undergang fra 1923 Sloterdijk er meget fascineret af, selvom han afviser bogens determinisme - at en tidsalder vokser, blomstrer og visner. Forskellen mellem Sloterdijk og Spengler er, at forholdet mellem cynisme og kynisme ifølge Sloterdijk kan ændre sig flere gange i historiens løb, historien kan korrigeres, for selvom den er slået fejl og virker deterministisk, så er det altid muligt at gribe og ændre historiens gang. Sloterdijks projekt rummer således en tragisk selvopfattelse, en viden om, at hans filosofi er endnu et led i et work in progress, fra myte til historie, og det er det, der gør hans læsninger af oplysningstiden og weimarrepublikken interessante. Smertens apriori er netop indsigten i denne række af historisk fejlslagne forsøg på at vende tilbage til den oprindelige cynisme, som Sloterdijk også kalder en eksistentialisme, og hvis drivkraft er såret:

"Det er kulturens hårdtsårede, der under store anstrengelser finder noget helbredende, der kan få kritikkens hjul til at dreje videre. Adorno har tilegnet Heine et 
kendt essay, 'Såret Heine'. Det er ikke anderledes end det sår, der borer og nager i enhver betydelig kritik. Overalt i det modernes store kritikpræstationer er der åbne sår: Såret Rousseau, såret Schelling, såret Heine, såret Marx, såret Nietzsche, såret Spengler, såret Heidegger, såret Theodor Lessing, såret Freud, såret Adorno. Kritik opstår af store sårs selvhelinger, for tidsaldrene tjener de som samlingspunkter for selverfaring. Enhver kritik er et pionerarbejde i tidssmerte og et stykke eksemplarisk heling." (Sloterdijk, Kritik 25)

Ved at skrive sig ind i denne lange tradition peger Sloterdijk også på den sætning om filosofiens fremtid, som skulle være en modsætning til Adornos sætning, om filosofiens overvintring i det lukkede samfund i det 20. århundrede. Ordet opgave brugte Sloterdijk om sit projekt med at give historiens en genkomst, men Aufgabe betyder både opgave og opgivelse, og spillerummet mellem opgivelse og opgave betyder, at det at filosofere i dette lille mellemrum på samme måde som hos Benjamin er en lykke for dem uden håb. Og det er Sloterdijks opgave at måle andres og egne evner til at sprænge sig vej ud af opgivelsen, det er et mål, han sætter sig selv, og som kommer til udtryk i analysen af oplysningstiden og af Weimarrepublikken.

I begge tilfælde, både i oplysningstiden og i Weimarrepublikken, er der tale om, at udgangspunktet er at bryde kynismens lammelse, og tro på forholdenes determinisme, gennem en fornuftskritik. Men begge steder ender den indsigt i determinismen, der skulle medføre frihed fra determinisme, i resignation. Det gælder allerede for Kant, der egentlig skrev kritikken af den rene fornuft for at afgrænse denne fornufts objektfelt - naturbeherskelsen, i forhold til etik og æstetik, men endte med at overføre formalismen til al erkendelse, sådan som Adorno allerede redegjorde for det i Negativ dialektik, og denne endimensionalitet gælder ifølge Adorno og Sloterdijk også for Marx, hvis analyse af den politiske økonomi endte med at være skeptisk over for muligheden af en emancipation fra de økonomiske muligheder for frihed i et klasseløst samfund. Sloterdijks Marxkritik er vigtig, fordi den er omfattende, han leder ikke efter nogle fejl, der kan rettes, han siger tværtimod, at der må være noget galt med hele tankeuniverset, som udløser en kynisme i hele den marxistiske teoris virkningshistorie. Og en af grundene til, at Kritikken af den kyniske fornuft fik så stor en gennemslagskraft, var uden tvivl, at Sloterdijk analyserede Weimarrepublikkens fejlslagne udvikling som et forstadium til Tyskland i I980erne, som en advarsel om konsekvenserne for nutiden, hvis man ikke tog kynismens politiske konsekvenser alvorligt og hengav sig til den muntre postmodernisme og dens opgivelse af de store utopier. Nazismen definerer Sloterdijk som kynismens kynisme.

Bogen om Kant begynder med sætningen "Viden er magt", det er Foucault, men mens Foucault opfatter magt som noget ontologisk, leder Sloterdijk stadig efter modstandsområder mod magten, og finder dem to steder, $i$ kunsten og i en kritik af objektfilosofien, for eksempel i en kritik af Habermas og hans formålsrationalitet. De kunstnere, han nævner, er Diderot, Heine, Rilke, Brecht, Jünger og Benn. De filosoffer, han bygger på, er frihedsfilosoffen Fichte, Bakhtins karneva- 
lisme, Ernst Bloch, Benjamin og Nietzsche. Derimod ikke Heidegger. Netop i det advarende afsnit om weimarrepublikken tager han forbehold overfor Heidegger, fordi hans teori om Sorge udelukker en teori om lykke, ikke meget anderledes end hans opfattelse af Adorno, hvis negativitetsteori ifølge ham ender med at bekræfte determinismen, som den var rettet imod.

\section{Det magiske trce og kroppens 'lad mig vare i fred apriori'}

Kritik af den kyniske fornuft slutter i munter afmagt, for på den ene side indskriver Sloterdijk sig i en lang tradition for at påtage sig en opgave, der er præget af en tendens til opgivelse overfor historiens "lort", dvs. historiens evige gentagelse, og på den anden side indskriver han sig i rækken af filosofiske temperamenter, der vælger friheden som udgangspunkt i modsætning til den kulturpessimisme, han konstaterer hos mange af sine samtidige. Udvejen er allerede antydet i Kritik af den kyniske fornufts gennemgående flertydighed i forholdet mellem kynisme/cynisme, mellem Kant, der aldrig rigtig gennemgås, men er til stede overalt, som kyniker og cyniker, og i anvendelsen af de mange billeder, der både illustrerer og peger ud over sig selv hen mod friheden fra den rene formålsrationalitet. Skildringen af denne friheds muligheder for at bryde historiens mytiske gentagelse og muliggøre en egentlig historie med utopier og myndighed, er emnet for Sferer I-III, men dette kæmpeværk forberedes først af to skrifter, der peger frem mod det centrale begreb om nobjekt, dvs. det modsatte af objektfilosofien, som er central for Sfærer I-III.

Sloterdijk skriver i 1985 en bog, som han ikke kalder en roman, men en historie og "et episk forsøg over psykologiens filosofi", bogen hedder Det magiske trce - Psykoanalysens tilblivelse i I785. Et episk forsøg er også den efterfølgende bog af Sloterdijk Tankeren på scenen - Nietzsches materialisme, som især handler om den æstetiske retfærdiggørelse af verden i spillet mellem det apollinske og det dionysiske i Nietzsches tidlige hovedværk Tragediens fødsel af musikkens and og som faktisk er en lille Nietzschebiografi. På den måde indskriver Sloterdijk sig i en tradition, som går tilbage til Siegfried Kracauer, Walter Benjamin, Blanchot, Sartre og mange andre af det 20. århundredes filosoffer, der søger at løse problemet med formålsrationalitetens dominans i moderniteten ved at forene billede og begreb til tankebilleder.

Det magiske tra handler om en ung mand, Jan van Leyden, der i 1785 forlader Wien for at drage til Paris og dér få indsigt i mesmerismen. I Paris møder han Marquis de Puységur, der præsenteres som opfinderen af den kunstige somnambulisme, dvs. at mennesket består af to personligheder, den somnambule og den normale, der sameksisterer i samme person. Puységurs lærer Mesmer mente, at hele universet var gennemstrømmet af et magnetisk fluidum, og til sidst i romanen danser en gruppe psykisk syge rundt om det magiske træ, som fandtes på Puységurs gods i Frankrig og som er magnetiseret af Puységur,, og derefter drager Jan van Leyden tilbage til Wien, nærmere bestemt til Berggasse 43, for at fortælle normalitetsfilosoffen Freud, at han har misforstået sin opgave, som er at konfrontere sig selv med det ubevidste og ikke lade jeg blive til, der hvor der før var det ubevidste. Man 
skal ikke undre sig over, at romanen glider fra I785 til I90o, for eftersom Sloterdijk tænker morfologisk og ikke historiefilosofisk, kan han frit vandre mellem antikken og moderniteten og det samme princip er også gældende i den efterfølgende Nietzschebog, om tænkeren på scenen, for ifølge den findes der kun én scene, det er en verdensscene, fuld af formforandringer.

Bogen om det magiske træ er stærkt påvirket af den franske oplysningstids materialisme, især af Diderots Rameaus Nevø, der optræder som person i Sloterdijks roman, og af Fatalisten Jacques, og dens tema, som er at rejse uden et bestemt mål, men med flere sideløbende mål, der alligevel ender med at hænge sammen i et dunkelt, symbolsk punkt i udkanten af læserens erfaringsmuligheder.

Som et eksempel på mødet med mesmerismen må man se Van Leydens oplevelse af domkirken i Strasbourg, med det ene tårn, der uden besvær rejser sig op mod det grænseløse:

"Van Leyden følte sig brat tiltrukket af dette opsvings uhyrlighed. Gennem stenmassen mente han at se en bevægelse, der sugede hele hans følelse ind i dette frygtindgydende opad. Han kendte ingen, der allerede havde gjort noget lignende. Han lukkede øjnene og vendte tungt åndende ryggen til tårnspidsen.” (Sloterdijk, Der Zauberbaum 50)

Af sin ledsager får han at vide, at hvert tårn indeholder det moderne jegs oprindelseshistorie, for tårnets uoverskuelighed modsvares af et vildt indre, og trafikken mellem de to sammenbundne sfærer gør mennesket gennemsigtigt og porøst som en glødende meteor:

"Menneskeåndens skæbne afgøres af polerne overfor og indenfor. Kun den, der har slukket enhver glød, kunne for et syns skyld stille sig udenfor og tale 'om' alt, som om mennesket havde frigjort sig fra loven om overfor og indenfor.” (Sloterdijk, Der Zauberbaum 283)

Bag hele denne tårnoplevelse gemmer sig den unge Goethes essay "Om tysk bygningskunst”, fra I773, om hans svimmelhedsoplevelse, da han besteg domkirketårnet i Strasbourg og fattede det symbolskes øjebliksoplevelse, der både var indre og ydre, og som gjorde ham i stand til at fatte det universelle i urbilleder. Disse urbilleder var ifølge Goethe hjælpekonstruktioner, som hele tiden ændrede sig alt afhængig af den betragtendes ståsted. Netop disse urbilleder bliver centrale for udviklingen af nobjektteorien i Sfarer I-III.

Både Goethe og Diderot var forfattere og filosoffer og dannede en modvægt til begrebsligheden hos Kant og Hegel, og det er derfor Sloterdijk skal bruge dem i sit kommende projekt om Sferer, og det samme gælder den lille bog om Nietzsche, der faktisk er en fortsættelse af tematikken fra Det magiske træ, dog ikke omhandlende mesmerisme, men forholdet mellem det dionysiske og det apollinske. I Nietzschebogen dukker Diogenes og det cyniske fra Kritik af den kyniske fornuft op igen, men 
i et nyt perspektiv. Ikke mere som latterens og karnevalismens urbillede, derimod som "den dionysiske redder af det alt for dionysiske".

For Sloterdijk er Nietzsches filosofi ikke antioplysning, men det, han kalder "dionysisk terapi". Det betyder, at han genindsætter Nietzsche som en radikal oplysningsfilosof, der som de antikke cynikere stiller spørgsmålstegn ved alt: religion, idealisme, moralisme, ressentiment. Men det gør han indefra, hans filosofi er en psykodramatisk scene, hvor han med sig selv som hovedperson spændt ud mellem det apollinske og det dionysiske afslører, hvor porøs det moderne jeg er. Men for at kunne gennemføre denne læringsproces og udholde smertegrænsen for eksperimenter med jegets muligheder $\mathrm{i}$ en kaotisk tidsalder, er Nietzsche nødt til at anvende det dionysiske i anførselstegn, og det gør han ved at tænke konflikterne som indre drama, som tragedie, som musikdrama, og ikke som politik, hvor det dionysiske ville være irrationalisme, med alle de traumatiske følelser, det ville få for en tysk filosof efter anden verdenskrig. Helten i det antikke drama var Ødipus, i det moderne drama er det ifølge Sloterdijk ironikeren, der dybest set er i chok over at se og føle den gamle verdens apollinske harmoni rystet af den moderne verdens dionysiske kaos:

"På denne måde sætter Nietzsches teatralske selverfaring et perfekt system af selvskuffelser i værk. Uanset, hvad der siger jeg på scenen - så vil det være et symbolsk forestillet jeg, en apollinsk kunstfremtoning, som vi holder op for os som et slør, for ikke at gå til grunde overfor den fulde sandhed.” (Sloterdijk, Europtaoismus 7I)

Sloterdijk har flere ord for denne særlige terapi, tragisk terapi, psykonautik, for at angive, at denne læringsproces er uendelig, og derfor vender Sloterdijk tilbage til sin Nietzschetolkning i en senere bog, med titlen: Du må andre dit liv, nemlig fra kun at være formålsrationalitet, og til at kunne håndtere ursmerten, eller smertens apriori:

"Lad os sige det sådan: Ved faldet fra livmoderen og ud i senkapitalismen ophober der sig en individuationssmerte, som man ikke som sådan kan gøre senkapitalismen ansvarlig for - selv om denne refleks er nok så nærliggende og uanset, hvor talrige de diskurser måtte være, der under vores instinktive jagt på den skyldige siger, hvor han skal findes. For at forarbejde denne smerte, der ikke hører hjemme i samfundsformationen, men til livscyklussen, subpolitisk, er en selvbevidst antipolitisk terapi nødvendig - ikke for at afpolitisere individerne, men for at afneurotisere politikken.” (Sloterdijk, Europtaoismus I86)

Dermed bliver Nietzsches lære om den æstetiske retfærdiggørelse af livet det modsatte af en kynisk æsteticisme, smerten placeres i en indre, immanent livssfære, i en boble af rus og drøm, som Sloterdijk kalder det og som ifølge ham er nødvendig for den immanente læringsproces. På den måde læses både Goethe og Nietzsche som eksempler på nobjektteorien, og på opbygningen af Sferer, hvis to første bind skildrer den mytiske verden, der varer fra Platon til det 20. århundrede, mens det 
sidste bind handler om det moderne som en chokoplevelse, men også som et forsøg på at bryde ud af myterne, morfologien og give mulighed for en ny historie.

\section{Sferer af bobler, glober og skum}

Hovedtemaet i Sferer er en undersøgelse af grundene til angsten hos det moderne menneske over for frihed fra traditioner og fra historie som menneskehedens forhistorie. Det er en genoptagelse af den europæiske venstrefløjs opdagelse af psykiske bindinger til autoriteter og fortid, som i mellemkrigstiden ${ }^{6}$ gjorde det svært at argumentere for socialisme og let for demagoger at argumentere for fascisme. Med baggrund i sin analyse af mesmerisme, Goethe og Nietzsche skildrer Sloterdijk nu de indre forhindringer for denne læringsproces.

Den begynder med fødslen, og indtil fødslen befinder vi os i det føtale stadium, $i$ en sfære af rund, harmonisk tryghed, men fødslen er ursmerten, som vi aldrig forvinder, fra dag et til vores død tilgiver vi aldrig, at vi forlod livmoderen, og resten af livet består i at lære at leve med smerten og den afbrudte lykke i objektverdenen og blive psykonautikere som Nietzsche.

I forordet til Oplysningens dialektik skrev Adorno/Horkheimer, at de ikke mere kunne stole på den eksisterende videnskab som grundlag for deres diagnose af oplysningen, fordi den var en del af oplysningens omslag til myte, og derfor er allerede deres værk præget af litterære referencer til Odysseen og til Odysseus som den første borger, og af en omvending af Hegels dialektik fra at være positiv til at være åben og ikke bekræftende. Men Sloterdijk ville aldrig sige, at Odysseus er den første borger, tværtimod bygger han sit trebindsværk op på et skarpt skel mellem "kugletiden", dvs. antikkens platoniske opfattelse af at befinde sig i et harmonisk, beskyttende rum for den enkelte og for almenheden, og "vandtiden", som er den moderne argonautiske tid, hvor kuglen og globussens symboler erstattet af skummets tid.

Trebindsværket Sfarer foregår i rum - Sloterdijk opfatter sit værk som et værk om væren og rum - og hele begrebsinventaret fra Kritikken af den kyniske fornuft er skiftet ud med kosmiske symboler, som allerede var forberedt i mesmerismens magiske træ og i Goethes metamorfoselære og i referencen til Wagners Ringtrilogi i den lille Nietzschebog, som forspil til de tre Sfære-bøger. Tanken om at opleve det dionysiske i anførselstegn og ikke direkte, er også Goethes symbollære om at opleve alt gennem et organisk billedsprog og gennem naturens urbilleder, og ikke gennem Hegels historiske dialektik. Og mens Sloterdijk koketterede med at bruge Spenglers bog om Vesterlandets undergang i sit tidligere forfatterskab, så er det nu hans bog, der er hovedinspirationskilden for Sferer, det er Spenglers brug af Goethes metamorfoselære og hans brug af Nietzsches dobbelthed af det dionysiske og det apollinske, der er centralt, selvom Sloterdijk kritiserer determinismen hos Spengler og ligeledes Spenglers stadig altfor store optagethed af positivisme og

6 Se: "Studies in the Authoritarian Personality" in: Adorno, Gesammelte Schriften 9.I. 
kendsgerninger. Adorno skrev i 1950 et essay om Spengler med titlen "Spengler efter undergangen", hvor han viste, at Vesterlandets undergang havde fascineret hele generationen i mellemkrigstiden i kraft af sit billedsprog og i kraft af sine forudsigelser af kulturindustrien og den moderne storby, og på samme måde går Sloterdijk også på jagt i Spenglers strandede kæmpeværk og redder det i land, som han kan bruge i sin bestræbelse efter at opdage og modvirke fortidens bindinger. Det er hele kæmpeperspektivet af historien tolket morfologisk, som en beskrivelse af udviklinger og tendenser i rum; hele pointen med at bruge Spengler i Sferer er dybt ironisk, for hans værk og determinisme er et frygteligt billede på, at vi stadig lever i mytisk tid, at vi ikke er kommet længere, på trods af alle forsøg på at indføre frihed og oplysning, og historie, på trods af Kant, Hegel, Marx, Nietzsche, Lukács, kritisk teori og Sloterdijk. Vi lever stadig i smertens apriori. Indtil vi læser Sferer I-III, og ikke mindst III.

\section{Opbygningen af Sferer}

Det giver mening at tale om historiens genkomst i forbindelse med udgivelsen af Sloterdijks Sferer, fordi han rent faktisk prøver at indfri det, han kaldte smertens apriori fra Kantbogen. Sferer er et angreb på det, han kalder objektfilosofien, dvs. traditionen fra Descartes og helt frem til nutiden. Sloterdijk er udmærket klar over, at denne kritik også var udgangspunktet for den tyske idealisme og for Hegel, for hermeneutikken og for eksistensfilosofien, især for Heidegger og nymarxismen, ikke at forglemme Adornos Negativ dialektik, men de var blot ikke radikale nok. De endte alligevel med at falde tilbage i en begrebslighed, og bekræftelse af objektet som det positive i dialektikken, som en bekræftelse af determinismen i historieopfattelsen hos Hegel og Marx og i opfattelsen af personligheden hos Freud.

Sloterdijk prøver nu at imødegå alt dette ved at indføre begrebet "nobjekt". Det betegner oprindeligt forholdet mellem mor og barn før fødslen, hvor der endnu ikke er tale om et subjekt-objekt forhold, men om et sfærisk forhold, hvor subjektets omgivelse endnu ikke er et objekt, men hvor de to poler går over i hinanden. Begrebet for denne prænatale erfaring bruger Sloterdijk til at angribe hele den "analytiske myte", dvs. den instrumentelle rationalitet, sådan som den kritiske teori allerede gjorde det, men blot kun i analytiske begreber og ikke i billeder og myter og store fortællinger, sådan som Sloterdijk nu gør det.

Ganske vist konstaterede Adorno/Horkheimer i indledningen til Oplysningens Dialektik, at man ikke kunne bruge den hidtidige tænkning til at kritisere oplysningens dialektik med, men de tænkte selv alt for abstrakt, og det samme gælder for Heidegger ifølge Sloterdijk. At det forholder sig sådan, det kan man se blot ved at betragte Sloterdijks måde at skrive på, især hans romankunst, hvor det fortryllede træs omsluttende og runde form bliver grundlaget for Sfarer, i inddragelsen af ord som sfærer, boble, kugle, bryster, insulering, vandverdener, skum, magisk tid, faustisk tid. 
Det mest overraskende af Sloterdijks greb er hans angreb på Heidegger.7 Ganske vist bruger han mange af hans begreber overalt i sit forfatterskab, han opgraderer ham også i forhold til den kritiske teori, men ender alligevel med at kritisere hans tidsfilosofi, hvorimod han ser ansatser til en rumfilosofi hos ham i brugen af ordet nærhed, som kan kobles sammen med nobjektbegrebet. Sfarer I-III er tænkt som Væren og Rum, det er Spenglers morfologi, som Sloterdijk er optaget af, og de tre bind er fuld af billeder, der ikke kun illustrerer teksten, men korresponderer med den og giver læseren fornemmelsen af at befinde sig nachträglich i et prænatalt nobjekt-teater med hyppige sceneskift.

Første bind af Sferer er et angreb på Freuds dybdepsykologi og et stort anlagt forsøg på at omdefinere ordet ubevidst ud fra nobjekt-teorien. Det ubevidste hos Freud blev begrænset af hans optagethed af oplysningen og styrkelsen af jeget, Sloterdijk søger tilbage til antikken, til mesmerismen og til den romantiske naturfilosofi for at udvikle sit ubevidste. I stedet for Freud orienterer Sloterdijk sig hos Jung, hos den engelske psykoanalytiker Laing, hos utopifilosoffen Ernst Bloch - faktisk kalder han forholdet mellem jeg og omverden i det prænatale stadium for princip naboskab ${ }^{8}$ - og hos den tyske kulturfilosof Thomas Macho, som han har begrebet nobjekt fra:

"Det er efterhånden en offentlig hemmelighed, at den tidlige wiener-psykoanalyse blev stående på halvvejen, da den prøvede at trænge ind i den intersubjektivenærhedsverden med sit begrebslige armatur. På væsentlige punkter kan man med rette sige, at den i teori og praksis udviklede et system, der skulle være et forsvar mod uvelkomne nærhedserfaringer. [...] Over for dette har Macho påvist, at hele den psykoanalytiske begrebslighed for tidlige relationer er fundamentalt deformeret af objekt-fordommen - ja mere end det, at fikseringen til objektrelation-tænkningen er ansvarlig for den ligefrem fatale undervurdering af de føtale og tidlige virkelighedsmodi indenfor den ældre psykoanalytiske ortodoksi. Derfor ville det være et håbløst, for ikke at sige patogent projekt at beskrive den tidlige mor-barn virkelighed i objekt-relationsbegreber.” (Sloterdijk, Sphären I 297)

Sloterdijks interesse i det prænatale skyldes hans optagethed af smertens apriori, og hans kritik af den instrumentelle fornuft i den nyere filosofi. Og derfor er det interessant, at han vælger at illustrere sin teori med billeder og myter, som også Adorno og andre har brugt i deres kritik af oplysningens dialektik. Det gennemgående symbol i første bind af sfærer-serien er boblen, den skrøbelige sæbeboble, som Sloterdijk lader en lille dreng sende til vejrs på bindets første sider, og som symboliserer den prænatale tilstand, der ophører med fødslen. Men erindringen om ikke-objekterne fortsætter med at melde sig, efter fødslen som sfærisk musik

7 Selv i Sloterdijks bog om Heidegger - Nicht gerettet - Versuche über Heidegger fra 20oI mærker man et stort forbehold overfor Heideggers provinsialisme, et forbehold, som Sloterdijk deler med Adorno.

8 Ernst Blochs hovedværk hed Princip håb. 
- det er et af Machos vigtigste eksempler - som englesang, og som sirenesang, den vi kender fra Homers Odysseen, som spiller en vigtig rolle i Oplysningens dialektik af Adorno/Horkheimer. Mens de er optaget af arbejdsdelingen mellem Odysseus, der bundet til masten kynisk kan forstå og forsmå kunstens utopi, og de roende mænd, der arbejder og intet hører andet end kulturindustriel slaverytme, så er Sloterdijk optaget af, at sirenesangen er opfyldelse for Odysseus, at den er hans egen sang, der minder ham om den nærheds-verden, han forlod, da han blev født, og som han stadig stræber efter at realisere ved et øjeblik at glemme rejsen som en subjekt-objekt rejse til fordel for en utopisk opfyldelse:

"Hvis der ikke stadig fandtes mange, der havde evnen til positiv deltagelse i forklarelsen af den store anden, så ville Andy Warhols afstumpede bonmot om femten minutters berømmelse for alle faktisk være en beskrivelse af den sidste horisont for en civilisation, hvor berømmelsen i mere end én valuta blev ædt op af inflation ... Odysseus ved masten ... Hvor det lykkes at forbinde sirene-effekten med Pantheoneffekten, der forplanter kulturens lydbølge sig diskret og uimodståelig til subjekterne. Kultur er indbegrebet af alle forventede og udtalte laudationer."(Sloterdijk, Sphären I 508)

I et sådant citat er der ikke kun referencer til Andy Warhol og den kritiske teori, men til Ernst Blochs Princip håb og dagdrømmenes betydning for utopien og til Spenglers værk om Vesterlandets undergang, der rummer en lang og central analyse af Pantheon-templet i Rom.

Andet bind af Sferer indeholder en vigtig analyse af Pantheontemplet i Rom. Hvis nøgleordet for første bind er boblen, som den opleves af barnet i det prænatale stadium, så er det kuglen eller globussen for andet bind. Tanken er, at verden indtil renæssancen og opdagelsen af Amerika i I492, og faktisk helt frem til det 20. århundrede, var omfattet af en kæmpekugle, og ligesom den enkelte vagt mindedes den prænatale tilstand, så er Platons filosofi kuglens filosofi, han er ifølge Sloterdijk en geometer:

"Og hvad er en Geometer? - en intelligens, der kommer fra de dødes verden og bringer vage mindelser om opholdet i en fuldkommen sfære med sig ind i livet.” (Sloterdijk, Sphären I II)

Hele bind to er en analyse af kuppelbygninger, af globusser, af Pantheon i Rom, med hullet i midten som Platons ideer anes igennem af os, skyggevæsenerne, der står og ser op mod den anden verden, og mindes vores egen tabte anden verden af engle og sirener. Spenglers analyse af Pantheon mundede ud i, at bygningen var forløberen for Hagia Sophia i Konstantinopel, der fra I453 blev moské, og dermed i mange århundreder indbegrebet af en magisk bygning, hvor det transcendente altid allerede var indeholdt i kuppelformen som universet. Sloterdijk arbejder videre 
med denne analyse, men hans analyse har et andet sigte end Spengler. Hans analyse placerede Panteheon og Hagia Sophia og Aya Sophia i hver sin tusindsårsfase.

Men Sloterdijk mener, at vi stadig er platonikere, vi har ifølge ham aldrig overvundet ideernes rige, vi tror stadig, at vi lever i en harmonisk sfære, og den første til at se dette chokerende træk, er Nietzsche, der i sit sene forfatterskab, i i88oerne, ikke blot konstaterede, at Gud var død, men opdagede de enorme konsekvenser, det medførte for os, de moderne. Det er derfor Sloterdijk i sin Nietzscheanalyse i Tankeren på scenen fremhæver, at Nietzsche kun bruger det dionysiske i anførselstegn, at han i virkeligheden i al sin modernitetsangst er apollinsk, og det bygger Sloterdijk på det følgende citat af Nietzsche, som indgår i hans lille bog om Filosofiske temperamenter:

"I den berømte aforisme 344 fra Den muntre videnskab: 'Hvorvidt også vi stadig er fromme' har antiplatonikeren Friedrich Nietzsche rejst et både ærefuldt og problematisk mindesmærke for grundlæggeren af Athens akademi: 'Men man har sikkert forstået, hvad jeg sigter til, nemlig at vores tro på videnskaben stadig hviler på en metafysisk tro - at også vi, de erkendende i dag, vi, de gudløse og antimetafysiske, stadig henter vores ild fra den brand, som en årtusindgammel tro har tændt, den kristen-tro, der også var Platons tro, at Gud er sandheden, at sandheden er guddommelig ... men hvad nu, hvis netop dette bliver stadig mere utroværdigt ...' Man kan forestille sig den europæiske filosofis historie som en stafet, der bærer en ild, tændt hos Platon og hos nogle af hans forløbere, navnlig Parmenides og Heraklit - fra generation til generation.” (Sloterdijk, Du musst II)

Sloterdijk taler ligefrem om Platons filosofi som en verdenshule, og i denne hule med kuppel halvsover den orientalske verden stadig i en fornuft, der er sat i stå, hvorimod de europæiske kirker, Sankt Peterskirken i Rom og Sankt Paul i London, ændrer karakter i forhold til Pantheon, og stræber opefter, bliver oceaniske og forlænger det immanente op i uendeligheden. Mens Pantheon er en triumf for det platonske evighedsrum, er de europæiske kupler en triumf for det oceaniske rum, opdagelsen af mennesket og menneskene, og det er jo så allerede begyndelsen til bind tre af Sferer, der hedder Skum.

I bind tre af Sferer viser det sig, hvor svært det er for Sloterdijk, at formulere alternativet til den kosmiske verdenskugle, og optere for en verdenskugle, for hele tiden hviler Spenglers og Adornos pessimistiske skygge over ham. For - spørger han - er det moderne i virkeligheden ramt af en undergang, som Spengler mente, eller af et efterliv, som Adorno mente, eller er der en fremtid, som er fundamentalt anderledes end det førmoderne, eller sagt på en anden måde: er der noget, der hedder historiens genkomst? Har Nietzsche ret? Er vi ikke kommet os over chokket. Sloterdijk taler med to stemmer, han siger både, at vi nu lever i en faustisk tidsalder, i en uendelig fremtidsrettethed og, at vi lever i fortidens massive "Schein", og når selv Nietzsche gør det, hvordan skal vi andre så kunne undgå det. Om det moderne siger Sloterdijk: 
"Er det en post-metafysisk tidsalder, som det lyder fra alle lærestole, eller en anderledes metafysisk tidsalder, der endnu ikke helt har forstået sig selv?” (Sloterdijk, Sphären I 474)

Her er der kun én, der kan hjælpe, og det er Diogenes, der dukker op igen, og med sin karnevalistiske latter baner vejen for det moderne. Men selv det er ikke helt overbevisende, for Sloterdijk opererer med tre former og faser af globalisering, den længste er den gamle, platonske, der varer til I492, den anden er den klassiske modernisme, der varer frem til I945, og den tredje er massemediernes og teknologiens tidsalder, og ingen af dem rummer den pessimisme, som ellers kendetegner andre definitioner af globalisering fra Ulrich Beck og Huyssen og til Appadurai.

Den første modernisme fra 1492 til det 2oende århundrede kalder Sloterdijk for Vandverdenen. Så længe mennesket befandt sig i Platons eller kristendommen sfæriske kugle, havde det fast grund under fødderne, men det moderne er oceanisk tid, det er de store opdagelsers tid, hvor rejser foregik med skib, og dette tidsrum har Sloterdijk beskrevet i bogen Im Weltinnenraum des Kapitals (I Kapitalens verdensindrerum). Dette begreb stammer fra Rilkes digtunivers og betyder et rum, hvor det transcendente er inderliggjort som del af et jordisk rum, og hvor man føler at kunne gå ud og ind mellem liv og død. Netop det er Sloterdijks pointe. I den moderne globalisering er kugler og glober noget, som det moderne subjekt tegner som kort over den verden, der skal kortlægges og erobres, og selv om verden ofte som hos den opdagelsesrejsende Alexander von Humboldt kaldes Kosmos, så er dette en æsteticering af en immanent verden, og uanset hvor langt de opdagelsesrejsende rejser i denne verden, så vender de altid tilbage til den immanente jord. Derfor erstattes kuglen og globen, som mennesket var en del af, nu med skum i tredje bind af Sferer: skum som det, der skabes, når opdagernes skibe krydser havet; og hvis der stadig er en uendelighed forbundet med havet og vandet, så ligger den i den moralske uendelighed. Subjektet kan ikke mere stige opad i sfærerne, når det koloniserer, men derimod nedad, vandfladens uendelighed modsvares af en moralsk frihed til at eksperimentere med verden på godt og ondt, som det allerede fremgår af de brutale europæiske koloniseringer af Afrika og Amerika, og af romaner som Moby Dick af Melville eller af Poes roman om Arthur Gordon Pym.

Men det er interessant at sammenligne Sloterdijks beskrivelse af den klassiske modernisme med Adorno/Horkheimers beskrivelse af Odysseus som den første borger, der drager gennem det græske øhav i antikkens tidsalder, som om det allerede var nutiden. Adorno/Horkheimers formål med at lade det moderne begynde i antikken var at imødegå enhver fristelse til at se fortiden som et religiøst eller mytisk alternativt flugtpunkt til nutiden, og på det punkt er Sloterdijks historieopfattelse helt modsat, han mener, at Adorno/Horkheimer undervurderede fortidens magt over det moderne menneskes vilje til at blive absolut moderne, og Slotersdijks alternativ til den moderne periode går helt frem til renæssancen, ja måske har den klassiske kugletid stadig gyldighed i dag. Og hvis Adorno/Horkheimers antikke hav er et instrument for oplysningens subjekt og dets beherskelse af naturen, så 
er Sloterdijks moderne subjekt ikke lig med “ingen”, som Odysseus kalder sig, da Kyklopen spørger, hvem han er, men dette subjekt er tværtimod lig med eventyr, opdagelse og mere end det. Det religiøse lever videre i de europæiske dynastiers selvforståelse som solkonger og messiasskikkelser helt op i det 20. århundrede, og det er enorm vigtigt for Sloterdijks historieopfattelse, at han opfatter disse symboler som langt mere end ideologi:

"Uden de indre konge-ikoner havde de fleste ekspeditionsledere i den tidlige globaliseringsperiode ikke vidst, hvem deres erobringer var til gavn for. [...] Globaliseringsrepræsentanterne, vicekongerne, admiralerne og deres officerer bærer side om side med deres religiøse forestillinger også deres dynastiske ledebilleder i deres indre og med ud i det fjerne. [...] Deres virke kan sammenlignes med den platonske lysstråles adfærd. [...] I denne forstand er alle loyale europæiske erobrere og opdagelsesrejsende på farten som fjerne solkongers eksekutive stråler.” (Sloterdijk, Im Weltinnenraum 204)

Derfor begynder den virkelige cæsur mellem den store religiøse og mytiske fortid og det moderne hos Sloterdijk først i begyndelsen af det 20. århundrede, han kan endda nævne en præcis dato:

"Det 20. Århundrede begyndte spektakulært afslørende den 22. april I9I5 med et specielt til lejligheden oprettet tysk 'gasregiments' første store anvendelse af klorgas som kampmiddel på vestfronten mod franske infanteristillinger.” (Sloterdijk, Sphären II 90)

I de traditionelle samfunds globale verden var den jordiske verden indlejret i en sfære af højere betydning. I den moderne tid går bevægelsen den modsatte vej, for alt det, der før regnedes for at være selvfølgeligt, bliver pludselig uvist, det, der før var en implicit del af livet, såsom åndedræt, luft, liv, bliver nu ekspliciteret, som gaskrig, som atomkrig, som vejrkrig, som luftforurening. Det medfører for Sloterdijk en helt ny form for hjemløshed, fordi det moderne menneske nu ikke kun fordrives fra den traditionelle globalisering, men fra den naturlige atmosfæres luft til klimatiserede rum, og i en revision af Heidegger siger Sloterdijk, at hele den ontologiske ramme ændres fra tilværen og bliver til luftværen.

I denne sammenhæng inddrager Sloterdijk Benjamins Passagevark, og hele omtalen af de forskellige sfærer, som Benjamin opdagede i de moderne bylandskaber, mellem gader, passager, vejr, lys, og ikke mindst i tærsklerne mellem den naturlige gades klima og passagernes "krystalpaladskulturer", der i Paris og andre af det I9. århundredes byer lå som øer med særlige eksistensbetingelser sammen med varehuse og drivhuse og vinterhaver.

I tredje bind af Sfærer konkluderer Sloterdijk, at den moderne by nu ikke mere består af nogle få afskærmede og overdækkede områder midt i resten af byen 
under åben himmel, men det hele er en foam-city, af "insulering", af kapsler, øer og drivhuse. Sloterdijk opererer ligefrem med tre forskellige insuleringsforhold: absolutte, atmosfæriske og antropologiske øer.

Absolutte øer er tekniske artefakter, undervandsbåde og rumfærger, der bevæger sig udenfor det almindelige beboede område og ind i perifere og farlige atmosfærer. Atmosfæriske øer er drivhuse, glashuse, kupler, med et særligt indeklima for mennesker og planter. De antropogene øer er et koncentrat af tidligere hytter, landsbyer og byer til foam-cities, til netværk af bobler, som rummer 9 forskellige værensmuligheder for det moderne menneske, snarere omstillingskrav, $i$ forhold til det traditionelle samfund, for det er alle kunstige rum.

\section{Du må cendre dit liv}

Tidligere i Sferer spurgte Sloterdijk, om det moderne var post-metafysisk eller anderledes metafysisk, og for at besvare dette spørgsmål har han skrevet en helt ny bog, Du mußt dein Leben ändern (Du må ændre dit liv) fra 2009. Her skriver han:

"Det moderne, der aldrig har kunnet være andet end radikalt, sækulariserer og kollektiviserer det øvende liv, ved at tage de traditionelle askeser ud af deres spirituelle kontekster, for at opløse dem i de moderne træning-, uddannelses- og arbejdssamfunds fluidum.” (Sloterdijk, Sphären II 5I9)

Det vil sige, at Sloterdijks moderne samfund både er post- og anderledes metafysisk, for den traditionelle askeseform går tilbage til antikken, til Platons idélære. Askese betyder øvelse, det er det enkelte menneske, der øver sig i at nå ideernes uopnåelige verden, gennem refleksion, gennem træning og sport, gennem kunst, ved at overgå sig selv og i fuld bevidsthed om opgavens umulighed. Titlen til dette værk om det nødvendige $\mathrm{i}$ at ændre livet er et citat fra Rilkes digt om Arkaisk torso af Apollon. Pointen i dette digt er netop, at læseren må ændre sit liv, fordi torsoen af Apollon er et fragment, ufuldstændig som værensbetingelserne for den øvende asket. Træningsarbejdet for den øvende er det, som Michel Foucault har beskrevet udførligt i Brugen af nydelserne fra 1984, og grunden til, at denne bog er vigtig for Sloterdijk, det er, at Foucault spørger, om den antikke askesetankegang virkelig er et alternativ til nutiden, eller blot en begyndelse til italesættelsen. Sloterdijks svar er Nietzsche, for det er fra ham, askesebegrebet stammer. Hvis Nietzsches filosofi begyndte med et meget forsinket chok over Guds død, og med fordrivelsen fra den klassiske globe, så tager Nietzsche derpå den enorme opgave på sig at definere askese som det moderne menneskes øvelse med at konstruere sig selv som moderne på basis af den gamle verdens ruiner. Sloterdijk skitserer flere muligheder for den moderne askese, det kommunistiske forsøg på at skabe det kommunistiske menneske med biologiske eksperimenter under navnet antropoteknik, eller Spenglers askeseform, som bestod i, at han inddelte historien i 8 kulturer, blandt andet den europæiske, hver på Iooo år, fra spiring over blomstring til afblomstring. Og Spenglers holdning 
til disse perioder, hvor den europæiske ville ende med nedgang og efterliv i det 20. århundrede, var præget af Spenglers videnskabelige kynisme, som Sloterdijk tager afstand fra. Hvis Spengler identificerede sig med de sejrende i historien, cæsarerne, identificerer Sloterdijk sig med det almindelige moderne menneskes forsøg på at øve sig i at være moderne. Men han frigør sig heller ikke fra den fortsatte brug af Spengler som billede på den mytiske tid, han "redder" ham. Han forbinder ikke den moderne askese med revolution, som kommunismen og nazismen gjorde det, men med evolution. Hans skitse til en moderne form for askese er forsigtig, men minder om Adornos meditationer om metafysisk i Negativ dialektik. "Kan dette virkelig være det hele”. Altså ikke en afvisning af enhver tanke om metafysisk for det moderne, men heller ikke fastlæggelse på en af de store ideologier:

"Renæssancens alvidende og pionererne indenfor den moderne tids forskende tænkning formulerede denne parole: 'Menneskene kan ved egen kraft alt, blot de vil.' De smækkede døren op til den postmiserabilistiske tidsalder, der var postmetafysisk, fordi den imødegik den eksistentielle tvang med intramundane svar. At tænke og handle postmetafysisk vil sige: At gå ud over den gamle condition humanas byrder ved hjælp af teknik og uden ekstreme asketiske programmer.” (Sloterdijk, Du musst 667).

Og med henvisning til Tour de France og Bjarne Riis' som eksempel på den ny asketiske nietzscheanisme hedder det:

"De eneste asketer i moderne tid, hvis sejr man ville ønske var autentisk, er atleterne.” (Sloterdijk, Du musst 667)

Altså ikke flere store ideologier, eller ideologer, men heller ikke moderne positivister som Bourdieu, som Sloterdijk tager fuldstændig afstand fra i Du må cendre dit liv på grund af hans populisme - Sloterdijk er en moderne tysk kulturkritiker og åndsaristokrat - men derimod samtale, og tro på en ny sølvalder, for hvorfor stræbe nostalgisk efter en guldalder eller frygte en jernalder:

"Man må på det bestemteste imødegå de stadig virulente venstreradikale ideologer, der på grund af skuffelse over den fejlslagne tilbagekomst til guldalderen, gør alt for at bagvaske sølvalderen som farce. Kun i en sådan samtale kan man gentage det fornuftige indhold i den noget overdrevent fremførte og endnu mere overdrevent afviste tale om 'historiens afslutning' efter Sovjetunionens sammenbrud...” (Sloterdijk, Du musst 670-67I)

\section{Udsigter}

Sloterdijks forfatterskab begyndte i i98oerne med en analyse af kynismen hos de intellektuelle som en afgørende grund til, at Weimarrepublikken led skibbrud og nazismen kom til magten. Han ser den samme kynisme på spil i I98oerne, 
hos de postmoderne, og hos de resignerede venstreorienterede, som har givet op over for den truende udvikling hen mod en højredrejning i Europa og i Tyskland. Hele hans forfatterskab anerkender, at forfattere som Heidegger (i ansatsen til en nærhedsontologi), Adorno, Spengler, Bloch, Benjamin, Habermas havde forstået denne fare, ved at redde mange af de ord og tendenser, som nazisterne brugte, således hjem, myte, idealisme, men de gravede ikke dybt nok, de var stadig forblændet af oplysningens evne til modgå længslen efter totalitære løsninger midt i det moderne. Derfor graver Sloterdijk dybere i Sfarer, ved at finde og tolke billeder af det prænatale og det kollektiv ubevidste om fra nostalgi til fremtid, fra kugler og huler til bobler og skum og krystalpaladser. Og det er ikke mindst Nietzsche, der er hans ledsager igennem inferno, purgatorium og paradis, fordi han i I88oerne opdagede, hvor meget vi stadig var bundet af den store platonske fortid, og hvilket kæmpearbejde med øvelse og askese det ville være at redde traditionens enorme magt over i det moderne og fremtiden. Hvis første og andet bind af Sferer skal vise os fortidens enorme magt og fascination gennem billeder, så skal sidste bind af Sfarer med dens insulære verdensbilleder og behovssystem vise os modbilledet, og sammen med $D u$ må andre dit liv være en handlingsanvisning for fremtiden. Netop fordi fortiden er en torso som Apollon, har vi grund til at øve os i en fremtid, der er lykkeligere end fortiden, historiens genkomst forudsætter et brud med myten.

Efter murens fald ser Sloterdijk ikke faren for en lammelse af demokratiet fra de store ideologier, men fra de intellektuelles dyrkelse af populismen, og fra aversionen mod alligevel at turde tænke i store fortællinger og bruge utopiske ord som lykke, luksus, overflod og ønske det næstbedste i stedet for det bedste. Det står og falder ifølge Sloterdijk med vores valg, mellem frihed eller determinisme, utopi eller dystopi, cynisme eller kynisme:

"Skæbnespørgsmålet er: om det lykkes at stabilisere standarterne fra den episodisk opdukkende sølvalder eller om tilbagefaldet til jernalderen står for døren, hvis aktualitet gamle og ny realister er overbevist om.” (Sloterdijk, Du musst 66I)

\section{LITTERATURLISTE}

Adorno, Th. W. Negative Dialektik. Gesammelte Schriften 6. Frankfurt am Main: Suhrkamp

Taschenbuch Wissenschaft, 1997.

Benjamin, Walter. Gesammelte Schriften I-I2. Frankfurt am Main: Suhrkamp, I974.

Bloch, Ernst. Das Prinzip Hoffnung, I-3. Frankfurt am Main: Suhrkamp Taschenbuch, I973.

Dobeneck, Holger Freiherr von. Das Sloterdijk-Alphabet - Kritisch-lexikalische Einführiung in seinen Ideenkosmos, Zweite stark erweiterte Auflage. Würzburg: Köningshausen \& Neumann, 2006.

Goethe, Johann Wolfgang. Werke. München: Hamburger Ausgabe I-I4, I98I.

Hegel, G.W.F. Werke I-20. Frankfurt am Main: Suhrkamp Taschenbuch, I97I.

Heidegger, Martin. Sein und Zeit. Tübingen: Max Niemeier Verlag, I993. 
Heinrichs, Hans-Jürgen. Peter Sloterdijk - Die Kunst des Philosophierens. München: Hanser Verlag, $20 \mathrm{I}$. Jongen, Marc, van Tuinen, Sjoerd, Hemmelsoet, Koenraad, (Udg.). Die Vermessung des UngeheurenPhilosophie nach Peter Sloterdijk. München: Wilhelm Fink Verlag, 2009.

Kant, Immanuel. Werkausgabe I-XII. Frankfurt am Main: Suhrkamp Taschenbuch, I977.

Nietzsche, Friedrich. Kritische Studienausgabe I-I5. München: de Gruyter, I999.

Spengler, Oswald. Der Untergang des Abendlandes - Umrisse einer Morphologie der Weltgeschichte.

München: C.H. Beck'sche Verlagsbuchhandlung (NB: Untergang des Abendlandes udkom først i to bind, hhv. i I9I8 og I922. Men den samlede udgave udkom i revideret form i 1923)

Sloterdijk, Peter. Kritik der zynischen Vernunft. Frankfurt am Main: edition Suhrkamp, I983.

Sloterdijk, Peter. Der Zauberbaum - Die Entstehung der Psychoanalyse im Hajr I785. Frankfurt am Main: Suhrkamp, I985.

Sloterdijk, Peter. Der Denker auf der Bühne - Nietzsches Materialismus. Frankfurt am Main: Suhrkamp Verlag, I986.

Sloterdijk, Peter. Europtaoismus - Zur Kritik der politischen Kinetik. Frankfurt am Main: Suhrkamp Verlag, I986.

Sloterdijk, Peter. Peter Sloterdijks "Kritik der zynischen Vernunft". Frankfurt am Main: edition suhrkamp, 1987.

Sloterdijk, Peter. Nicht gerettet - Versuche nach Heidegger. Frankfurt am Main: Suhrkamp Verlag, $200 \mathrm{I}$. Sloterdijk, Peter. Im Weltinnenraum des Kapitals. Frankfurt am Main: Suhrkamp, 2005.

Sloterdijk, Peter. Sphären I - Blasen. Frankfurt am Main: Suhrkamp, I998.

Sloterdijk, Peter. Sphären II - Globen. Frankfurt am Main: Suhrkamp, I999.

Sloterdijk, Peter. Sphären III - Schäume. Frankfurt am Main: Suhrkamp, 2004.

Sloterdijk, Peter. Du musst dein Leben ändern. Frankfurt am Main: Suhrkamp, 2009.

Sloterdijk, Peter. Philosophische Temperamente von Platon bis Foucault. München: Diederichs Verlag in der Verlagsgruppe Random House GmbH, 2009.

Sloterdijk, Peter. Mein Frankreich. Frankfurt am Main: Suhrkamp Verlag, 2013.

Sloterdijk, Peter. Scheintod im Denken. Von Philosophie und Wissenschaft als Übung. Frankfurt am Main: Edition unseld, Suhrkamp Verlag, 2oIo.

Tuinen, Sjoerd van. Peter Sloterdijk - Ein Profil. Paderborn: Wilhelm Fink Verlag, 2006. 
